\title{
Defect in export and synthesis of the periplasmic galactose receptor MglB in dnaK mutants of Escherichia coli, and decreased stability of the mglB mRNA
}

\author{
Abdelhamid El Yaagoubi, Masamichi Kohiyama and Gilbert Richarme
}

Author for correspondence: Gilbert Richarme. Tel: +33144275098 . Fax: +33144273580.

Génétique et Biochimie, institut Jacques Monod, Université Paris 7, 2 place Jussieu, 75251 Paris

Cedex 05 , France
The high-affinity galactose permease, which comprises the periplasmic galactose receptor MgIB, the membrane translocator MgIC and the membraneassociated ATPase MgIA, displayed a reduced activity in a dnaK temperaturesensitive mutant of Escherichia coli. This reduced transport activity correlated with a reduction in the quantity of $\mathrm{MglB}$. At $42{ }^{\circ} \mathrm{C}$, an accumulation of pre-MglB in the dnaK temperature-sensitive mutant reflected a defect in MglB export. In addition, an accumulation of pre-MglB in SecB, secA and secY mutants suggested that SecB and the Sec translocase are also involved in export of the periplasmic galactose receptor. At $30^{\circ} \mathrm{C}$, there was no accumulation of preMglB in the dnaK mutant, but there was still a decreased amount of MglB in the periplasm. The reduction in MglB expression was not the result of a decrease in its stability, nor was it the result of a general defect in translation or transcription, since the MglA protein (which is expressed from the same operon as MglB) was synthesized in normal amounts. Two mRNAs are implicated in the expression of the mgl genes, a polycistronic mg/BAC mRNA, and a more stable and more abundant mglB mRNA, produced by $3^{\prime}-5^{\prime}$ degradation of the mgIBAC mRNA (R. W. Hogg, C. Voelker \& I. von Carlowitz, 1991, Mol Gen Genet 229, 453-459). The mg/B mRNA is protected against exonucleases by a REP (Repetitive Extragenic Palindrome) sequence located at its 3' extremity, which is responsible for the higher expression of MglB compared to MglA and MglC. The decreased MglB expression in the dnaK mutant at $30^{\circ} \mathrm{C}$ in the present work correlated with a reduced stability of the mglB $m R N A$, which may have resulted from a defective stabilization by the REP sequence, or from a defect in translation of the mglB gene.

Keywords: heat shock protein DnaK, protein export, mRNA stability, Escherichia coli dnaK mutants, periplasmic galactose receptor

\section{INTRODUCTION}

Molecular chaperones form a class of polypeptidebinding proteins that are implicated in protein folding, protein targeting to membranes, protein renaturation or degradation after stress, and control of protein-protein interactions (reviewed in Ellis \& van der Vies, 1991; Georgopoulos et al., 1994; Hendrick \& Hartl, 1993). The major classes of molecular chapetones of Escherichia coli comprise DnaK/hsp70 (and its assistants DnaJ and GrpE), GroEL/hsp60 (and its assistant GroES) and

Abbreviation: REP, repetitive extragenic palindrome.
HtpG/hsp90. The heat shock protein DnaK/hsp70 (Georgopoulos, 1977; Bardwell \& Ctaig, 1984; Gross et al., 1990; Bukau \& Walker, 1989) plays a role in the maintenance of bacterial viability under stress, in addition to normal cellular functions. DnaK is a cytoplasmic protein, associated in part with the cytoplasmic membrane (Bukau et al., 1993; El Yaagoubi et al., 1994), which behaves as an ATP-dependent chaperone, facilitating the correct assembly or disassembly of cettain oligomeric protein complexes, and participating in protein folding and renaturation and in the transmembrane targeting of certain proteins (Wild et al., 1992). DnaK has also been implicated in cell division (Bukau \& Walker, 1989), murein synthesis (Wu et al., 1992), Alagellar assembly (Shi 
et al., 1992) and osmoregulation (Meury \& Kohiyama, 1991).

Protein export across the E. coli cytoplasmic membrane involves principally the Sec transport apparatus, which is composed of the SecB chaperone, and of a translocase comprising the SecA ATPase and the membtane-embedded SecE/SecY complex (Economou \& Wickner, 1994). Whereas SecB is considered to be the main chaperone for protein export, several pre-proteins are maintained in a translocation-competent state by the molecular chaperones DnaK/DnaJ (pre-PhoA) or GroEL/GroES (pre- $\beta$-lacamase), and these molecular chaperones probably substitute for SecB under conditions in which SecB becomes limiting (Wild et al., 1992). Furthermore, a signal recognition particle, similar to that found in eukaryotes, and which consists of at least one protein ( $\mathrm{Ffh}$ ) and one RNA molecule (4.5S RNA), functions as a chaperone specific for signal sequences in nascent pre-proteins and maintains their translocationcompetent conformation (Luirink \& Dobberstein, 1994).

The high-affinity galactose transport system of $E$. coli consists of the periplasmic galactose receptor $\mathrm{MglB}$, an integral membrane protein $\mathrm{MglC}$ and the membranebound transport ATPase MglA (Harayama et al., 1983). The $m g l$ genes are organized in the $m g l B A C$ operon, which is transcribed into an unstable polycistronic $m g l B A C$ mRNA. 'This is degraded in the $3^{\prime}-5^{\prime}$ direction up to a repetitive extragenic palindrome (REP) sequence located between $m g l B$ and $m g l A$, thus leading to the accumulation of a more stable $m g l B$ mRNA (Newbury et al., 1987a, b); Stern et al., 1988). The stabilization of the $m g l B \mathrm{mRNA}$ by its REP sequence is responsible in part for the higher expression of $\mathrm{MglB}$ compared to $\mathrm{MglA}$ and $\mathrm{MglC}$ (Hogg et al., 1991). In the present report, we show that dnaK mutations affect $\mathrm{MglB}$ export and expression, with a concomitant decrease in $m g l B$ mRNA stability.

\section{METHODS}

Bacterial strains. E. coli $\mathrm{K}-12$ strains $\mathrm{C} 600$ (leuB6 thi- 1 thr-1 supE44), WM1389 [C600 dnaK756 (ts)], MC4100 ( $\mathrm{F}^{-}$lacU169 araD139 thiA rpsL rel A), MM52 [MC4100 sec A51 (ts)], CK1953 (MC4100 secB: : Tn5), IQ86 (MC4100, Tn10) and IQ85 [IQ86 $\sec Y 24(\mathrm{ts})]$ were obtained from the laboratories of Drs J. Beckwith, K. Ito, C. Kumamoto, J. C. Walker and C. Georgopoulos. The strains were grown at $30^{\circ} \mathrm{C}$ in glycerol minimal medium. 'The $d n a K, \sec A$ and $\sec Y$ temperature-sensitive mutants were shifted to $42^{\circ} \mathrm{C}$ for several hours (as indicated) before the experiments. The high-affinity galactose transpott system was induced with $1 \mathrm{mM}$ fucose.

Transport measurements. The bacteria were washed twice at $0^{\circ} \mathrm{C}$ with minimal medium M63 (Miller, 1972) containing $0.4 \%$ glycerol and resuspended in the same medium. The washed bacteria were incubated for $10 \mathrm{~min}$ at $22^{\circ} \mathrm{C}$ before transport measurements. Galactose transport was assayed at $22^{\circ} \mathrm{C}$ in a volume of $1 \mathrm{ml}$ containing the equivalent of $50 \mu \mathrm{g}$ of cell protein per ml. D- $\left[{ }^{14} \mathrm{C}\right]$ galactose $\left(250 \mu \mathrm{Ci} \mu \mathrm{mol}^{-1}\right.$, Amersham $)$ was added to the bacterial suspension to a concentration of $2 \mu \mathrm{M}$. A $200 \mu \mathrm{l}$ sample of the assay mixture was removed from each flask at various times after the addition of the radioactive substrate and filtered through cellulose ester filters (Millipore HAWP, $0.45 \mu \mathrm{m}$ pore size). The filters were washed three times with $1 \mathrm{ml}$ of the transport medium and the radioactivity measured.

Cell fractionation procedure. The periplasmic fraction was prepared by the osmotic shock procedure described by Nossal \& Heppel (1966). The bacteria were plasmolysed at $16^{\circ} \mathrm{C}$ in $0.03 \mathrm{M}$ Tris/ $\mathrm{HCl}$ pH $7.3,20 \%(\mathrm{w} / \mathrm{v}$ ) sucrose, $0.2 \mathrm{mM}$ EDTA and osmotically shocked in distilled water containing $0.3 \mathrm{mM}$ $\mathrm{MgCl}_{2}$ at $0{ }^{\circ} \mathrm{C}$. The shocked cells were separated from the shock fluid (periplasmic fraction) by centrifugation at $10000 \mathrm{~g}$ for $10 \mathrm{~min}$. The cell lysate was prepared by ultrasonic disruption of bacteria in $50 \mathrm{mM}$ potassium phosphate, $\mathrm{pH} 6.8$ (Branson Sonic Power ultrasonicator, $25 \mathrm{~W}$, five times for $15 \mathrm{sec}$ each), followed by centrifugation of the mixture at $40000 \mathrm{~g}$ for $15 \mathrm{~min}$.

Immunoblots. Antisera against $\mathrm{MglB}$ and $\mathrm{MglA}$ were prepared in rabbits by immunization with $50 \mu \mathrm{g}$ protein in Freund's complete adjuvant. A booster immunization containing $50 \mu \mathrm{g}$ protein in Freund's incomplete adjuvant was administered after 3 weeks. Bleeding was performed $10 \mathrm{~d}$ after the injection. SDSPAGE and immunoblots were carried out according to Towbin et al. (1979). The intensity of protein bands was quantified with a Quick Scan densitometer (Helena Laboratories). MglB and $\mathrm{MglA}$ were purified as described previously (Richarme, 1983; Richarme et al., 1993).

Radiolabelling, immunoprecipitation and electrophoresis. Samples $(1 \mathrm{ml})$ of cells growing exponentially at $30^{\circ} \mathrm{C}$ in glycerol medium were pulse-labelled with $60 \mu \mathrm{Ci} \mathrm{m}^{-1}$ $\left.{ }^{35} \mathrm{~S}\right]$ methionine (Amersham, $1000 \mathrm{Ci} \mathrm{mmole}{ }^{-1}$ ), chased with nontadioactive L-methione $\left(200 \mu \mathrm{g} \mathrm{ml}^{-1}\right)$ and precipitated with TCA as described by Ito et al. (1981). The precursor and mature forms of $\mathrm{MglB}$ were immunoprecipitated, resolved by electrophoresis on SDS-polyacrylamide gels $[10 \%(\mathrm{w} / \mathrm{v})$ acrylamide $]$, detected by autoradiography and quantificd with an Ambis Scanner interfaced with an IBM computer.

RNA techniques. RNA for Northern blots was isolated by hot SDS/phenol extraction (Miller, 1972). Samples were separated on formaldehyde-agarose gels, transferred to nitrocellulose paper and hybridized to radiolabelled DNA probes in $50 \%$ (v/v) formamide as described by Maniatis et al. (1982). The size of RNA species was estimated by comparison with rRNA and denatured DNA markers. The probe used was composed of a 22 residue synthetic oligonucleotide complementary to residues 398-419 of the $m g / B$ mRNA (Hogg et al., 1991). It was labelled with $\left.{ }^{32} \mathrm{P}\right] A T P$ by polynucleotide kinase as described by Maniatis et al. (1982). Rifampicin was used at $200 \mu \mathrm{g} \mathrm{m} \mathrm{m}^{-1}$, a high concentration currently used for the inhibition of transcription initiation in E. coli in vivo.

\section{RESULTS}

\section{Decreased galactose transport and decreased amount of the periplasmic galactose receptor in dnaK mutants}

The dnaK756 thermosensitive mutant is defective in galactose transport. When transport was measured after growth at the permissive temperature $\left(30^{\circ} \mathrm{C}\right)$, the transport activity was sevenfold lower in the mutant than in the parental strain (Fig. 1a). When transport was measured after growth at $30^{\circ} \mathrm{C}$, followed by a shift to $42^{\circ} \mathrm{C}$ for $2 \mathrm{~h}$, the transport activity was tenfold lower in the mutant (Fig. 1a). The defect in galactose transport correlated with a reduction in the amount of periplasmic galactose receptor in the dnaK mutant. The amounts of $\mathrm{MglB}$ in the periplasm of the dnaK 756 mutant and of the parental strain C600 were measured by immunoblotting the periplasmic 


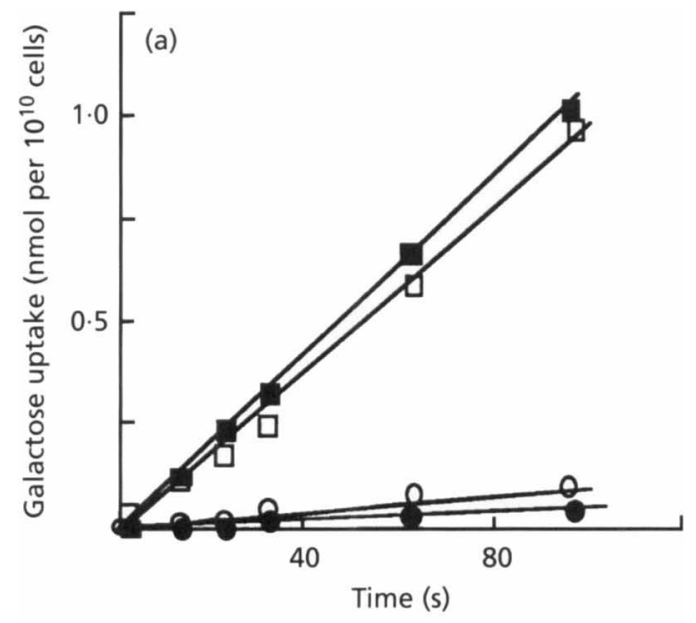

(b)

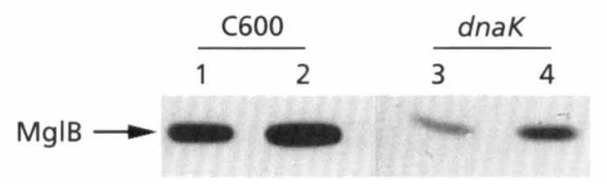

Fig. 1. (a) Decreased galactose transport in the dnak756 mutant. Galactose transport was measured as described in Methods at $22{ }^{\circ} \mathrm{C}$ in the wild-type strain $\mathrm{C} 600(\square, \boldsymbol{C})$ and in the dnaK756 mutant $(0,0)$, grown at $30^{\circ} \mathrm{C}(\square, 0)$ or grown at $30^{\circ} \mathrm{C}$ followed by a shift to $42^{\circ} \mathrm{C}$ for $2 \mathrm{~h}(\mathbf{0}, \mathrm{C})$. (b) Decreased amount of the $\mathrm{MglB}$ protein in the dnaK756 mutant. Periplasmic fractions from strains $\mathrm{C} 600$ and $d n a K 756$, grown at $30^{\circ} \mathrm{C}$, were prepared as described in Methods. The fractions were subjected to electrophoresis on a polyacrylamide gel and immunoblotted with anti-MglB antibodies. Column 1 and 2 contain, respectively, 7 and $20 \mu \mathrm{g}$ of the shock fluid from the parental strain 6600 . Columns 3 and 4 contain, respectively, 7 and $20 \mu \mathrm{g}$ of the shock fluid from the dnaK756 mutant.

fractions from both strains with anti-MglB antibodies. The amounts of $\mathrm{MglB}$ were fivefold lower in the dnaK mutant than in the parental strain at $30^{\circ} \mathrm{C}$ (Fig. 1b) and sixfold lower at $42{ }^{\circ} \mathrm{C}$ (not shown). The correlation between reduced transport activity and a reduction in the amount of galactose teceptor is consistent with the previous demonstration that when the periplasmic receptor of a binding-protein-dependent transport system is reduced to less than $20 \%$ of its wild-type level [while the other transport components remain at the wild-type level (see below)], it becomes limiting for transport (Manson et al., 1985). Similar reductions in galactose transport and in galactose receptot expression were found in the null dnaK mutant GW 4813 ( $\Delta$ dnaK52: : $\mathrm{Cm}^{\mathrm{r}}$ ) (Paek \& Walker, 1987) (not shown), suggesting that these defects ate common to several dna $K$ mutants.

\section{Defect in MglB export in the dnaK temperature- sensitive mutant at $42{ }^{\circ} \mathrm{C}$}

The efficient export of the galactose receptor to the periplasm of $E$. coli has been recently shown to be dependent on the presence of the SecB chaperone (Powers \& Randall, 1995). However, the following results suggest (a)

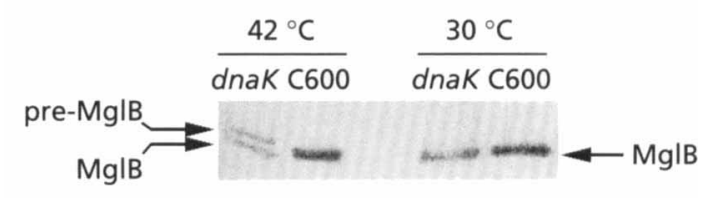

(b)

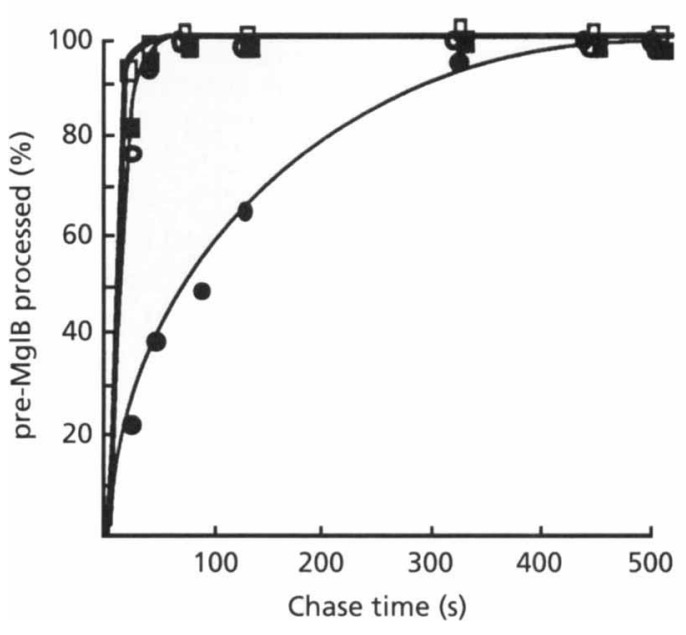

Fig. 2. (a) MglB precursor in the dnaK mutant at $42^{\circ} \mathrm{C}$. Cells growing exponentially in glycerol medium at $30^{\circ} \mathrm{C}$ (experiment indicated $30^{\circ} \mathrm{C}$, or growing at $30^{\circ} \mathrm{C}$ to $O D 0.7$ and then transferred to $42^{\circ} \mathrm{C}$ for $1 \mathrm{~h}$ (experiment indicated $42^{\circ} \mathrm{C}$ ), were pulse-labelled for $15 \mathrm{~s}$ with $\left[{ }^{35} \mathrm{~S}\right]$ methionine, chased with nonradioactive methionine for $30 \mathrm{~s}$ and precipitated with TCA. The galactose receptor was prepared from each sample by immunoprecipitation. (b) Kinetics of MglB export. Experiments were carried out as described in the legend to Fig. 2(a). Samples were pulse-labelled for $15 \mathrm{~s}$ and chased for the indicated times. The data are the average from two experiments. $\square, \boldsymbol{c}$, Strain $\mathrm{C} 600$ at $30^{\circ} \mathrm{C}(\square)$ or $42^{\circ} \mathrm{C}(\mathbf{\square}) ; 0.0$. dnaK756 mutant at $30^{\circ} \mathrm{C}$ $(0)$ or $42^{\circ} \mathrm{C}(0)$. Since the radiolabel was methionine and three of the nine methionine residues are in the leader sequence, a factor of 1.5 was used to convert the radioactivity recovered in the mature form to the amount of precursor polypeptide from which it was derived.

that $d n a K$ mutations also affect the export of $\mathrm{MglB} . \Lambda \mathrm{t}$ $42^{\circ} \mathrm{C}$, under conditions in which the parental strain contains only mature galactose receptor (pulse-labelling for $15 \mathrm{sec}$, chase for $1 \mathrm{~min}$ ), the dnaK temperaturesensitive mutant contains a significant amount of the galactose receptor as the precursor form (Fig. 2a). This secretion defect is not observed at $30^{\circ} \mathrm{C}$, at which temperature the MglB precursor does not accumulate either in the mutant or in the parental strain (Fig. 2a) [it should be noted that at both $30^{\circ} \mathrm{C}$ and $42^{\circ} \mathrm{C}$, the amount of $\mathrm{MglB}$ synthesized is reduced in the dna $\mathrm{K}$ mutant (see below)]. The half-time for complete export of $\mathrm{MglB}$ to the periplasm at $42{ }^{\circ} \mathrm{C}$ was approximately $1 \mathrm{~min}$ in the $d n a K$ mutant, compared to less than $10 \mathrm{sec}$ for the parental strain $\mathrm{C} 600$ (Fig. 2b), while at $30^{\circ} \mathrm{C}$, the kinetics of $\mathrm{MglB}$ export were similar in the mutant and in the parental strain. Thus, dnaK756 appears to be defective in its secretion of the galactose receptor at the restrictive 


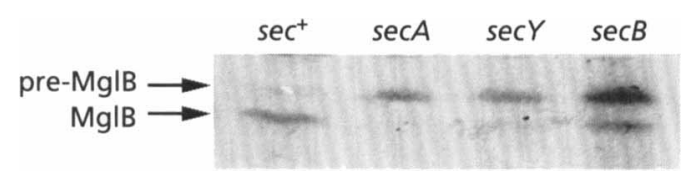

Fig. 3. MglB precursor in secB, sec $A$ and sec $Y$ mutants. Cells growing exponentially in glycerol medium at $30^{\circ} \mathrm{C}$ (strain CK1953 secB::Tn5), or grown at $30^{\circ} \mathrm{C}$ to $\mathrm{OD} 0.7$ and transferred to $42{ }^{\circ} \mathrm{C}$ for $2 \mathrm{~h}$ [strain MC4100 $\mathrm{sec}^{+}$, strain MM52 secA51 (ts), strain IQ85 secY24 (ts)] were pulse-labelled for $15 \mathrm{~s}$ with [35]methionine, chased with nonradioactive methionine for $30 \mathrm{~s}$ and precipitated with TCA. The galactose receptor was prepared from each sample by immunoprecipitation.

temperature, but not at $30^{\circ} \mathrm{C}$. While most of the exported proteins of $E$. coli interact with the SecB chaperone (Wild et al., 1992; Kumamoto \& Beckwith, 1983), some of them interact alternatively (MalE, LamB) or preferentially (alkaline phosphatase, PhoA) with DraK (Wild et al., 1992). Since DnaK is involved in many cellular processes, we cannot completely exclude an indirect effect of the dna K mutation on $\mathrm{MglB}$ export. However, the delay in the processing of pre-MglB to the mature species was already apparent after a $40 \mathrm{~min}$ shifr of the thermosensitive mutant at $42{ }^{\circ} \mathrm{C}$ (not shown), before the cells stopped growing (growth was severely impaired after 90 min and stopped after $3 \mathrm{~h}$ ). Furthermore, the SecB-dependent export of several proteins (OmpA, LamB) is not altered in dnaK mutants (Wild et al., 1992), suggesting that dnaK mutations do not affect the expression or the assembly of the Sec export apparatus.

\section{Involvement of the Sec translocase in MglB export}

The results shown in Fig. 3 indicate that, in addition to $\mathrm{SecB}$ and DnaK, the SecA and SecY components of the cellular export apparatus are involved in the export of $\mathrm{MglB}$. The $\mathrm{MglB}$ precursor accumulates in the $\sec B$ (IQ86), $\sec A$ (MM52) and $\sec Y$ (Kumamoto \& Beckwith, 1983; Ito et al., 1983; Oliver \& Beckwith, 1981) mutants, in conditions where the parental strains do not accumulate significant amounts of the precursor (Fig. 3). This suggests that the role played by DnaK in MglB export could be that of a chaperone functioning in parallel with $\mathrm{SecB}$ (or perhaps before $\mathrm{Sec} B$ ), and that membrane translocation of $\mathrm{MglB}$ requires the Sec translocase.

\section{Decreased MglB synthesis in the dnaK mutant at $30^{\circ} \mathrm{C}$ and $42^{\circ} \mathrm{C}$}

Further analysis of Fig. $2 \mathrm{a}$ shows that MglB expression is decreased in the dnaK 756 temperature-sensitive mutant, as deduced from the amounts of pulse-labelled $\mathrm{MglB}$ synthesized in the mutant and in the parental strain. At $42{ }^{\circ} \mathrm{C}$, there is a reduction in the amount of pulse-labelled $\mathrm{MglB}$ in the mutant $31 \%$ of the quantity synthesized in the parental strain, in both the precursor and mature form (Fig. 2a, compare lane 1 with lane 2). At $30^{\circ} \mathrm{C}$, in conditions where there is no apparent secretion defect, the amount of pulse-labelled MglB is reduced in the dnaK mutant $35 \%$ of the amount synthesized in the parental

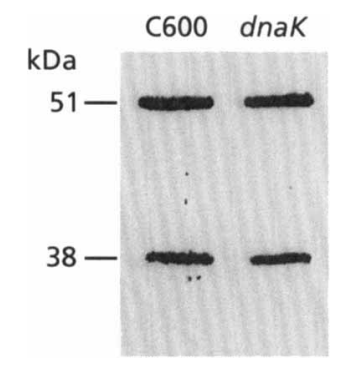

Fig. 4. Normal expression of MglA in the dnaK756 mutant. Cell lysates from the wild-type strain $\mathrm{C} 600$ and from the dnaK756 mutant were prepared as described in Methods and then $20 \mu \mathrm{g}$ of each lysate was loaded on an SDS-polyacrylamide gel and immunoblotted with anti-MglA antibodies. The band at $51000 \mathrm{Da}$ represents the $\mathrm{MglA}$ protein and the band at $38000 \mathrm{Da}$ represents its stable proteolytic product (Richarme et al., 1993).

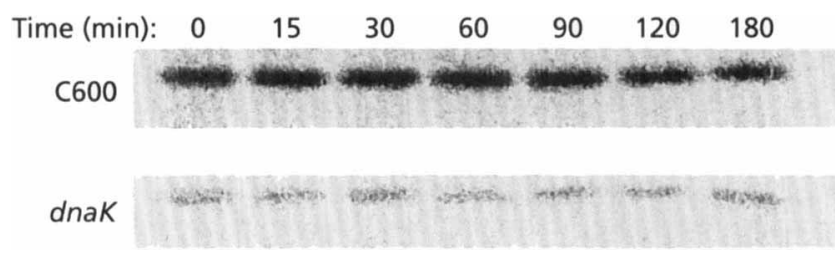

Fig. 5. Unaltered stability of MglB in the dnaK756 mutant. Cells growing exponentially in glycerol medium at $30^{\circ} \mathrm{C}$ were pulselabelled for $2 \mathrm{~min}$ with $\left[^{355}\right]$ methionine, followed by addition of unlabelled methionine to $0.04 \%$ (w/v). Aliquots were removed at various times after the chase and precipitated with TCA. The galactose receptor was prepared from each sample by immunoprecipitation.

strain, entirely in the mature form, Fig. 2a, compare lane 3 with lane 4). This decreased expression is selective for $\mathrm{MglB}$ : the MglA protein (the cytoplasmic galactosedependent transport A'TPase, which is expressed from the same operon, $m g l B A C$ ) is found in similar amounts in the dnaK mutant and in the parental strain, as shown in Fig. 4 where crude extracts from both strains are shown immunobiotted with anti-MglA antibodies. We checked, by pulse-labelling of $\mathrm{MgLA}$, immunoprecipitation and electrophoresis, that the synthesis of this protein was unaffected in the dnaK mutant (not shown). The expression of $\beta$-galactosidase was also not affected in the dnaK mutant (data not shown).

\section{Unaltered stability of MglB in the dnaK756 mutant}

The different levels of $\mathrm{MglB}$ expression in the dnaK756 mutant and in the parental strain might be due, in part, to different turnover rates. We measured the half-lives of $\mathrm{MglB}$ by labelling exponentially growing cells at $30^{\circ} \mathrm{C}$ with $\left[{ }^{35} \mathrm{~S}\right]$ methionine for $2 \mathrm{~min}$, followed by a chase with cold methionine. Samples were withdrawn at various times after the initial labelling, $\mathrm{MglB}$ was immunoprecipitated and submitted to electrophoresis. The $\mathrm{MglB}$ protein was very stable both in the dnaK mutant and in the wild-type strain (Fig. 5), suggesting that the dnaK 


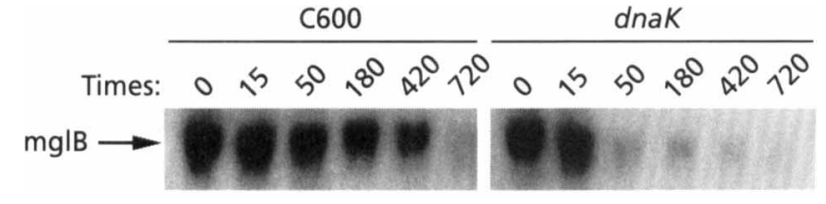

Fig. 6. Decreased stability of the $m g / B$ mRNA in the dnaK mutant. Northern blot of mRNA prepared from strain $\mathrm{C} 600$ and the dnaK756 mutant. Rifampicin was added to growing cells. RNA was extracted at various times after rifampicin addition and analysed by Northern blotting as described in Methods. Thirty micrograms of RNA from the dnaK756 mutant and $15 \mu \mathrm{g}$ of RNA from the parental strain $\mathrm{C600}$ were loaded into each well. Hybridization was to a labelled probe complementary to residues 398-419 of the $m g / B$ mRNA. Hybridization revealed the 1400 nucleotide $m g / B$ mRNA. No hybridization was seen when RNA was isolated from cells uninduced for the $m g l$ operon (grown in the absence of fucose and in the presence of glucose).

mutation has no significant effect on the stability of the galactose receptor. Similar results concerning the stability of $\mathrm{MglB}$ were obtained when labelling was done after a shift to $42^{\circ} \mathrm{C}$ for $2 \mathrm{~h}$ (not shown).

\section{Decreased stability of the $m g / B$ mRNA in the dnaK756 mutant}

As described above, the expression of $\mathrm{MglB}$ was decreased in the dnaK756 mutant, and the lower MglB expression resulted from a reduction in $\mathrm{MgiB}$ synthesis since the stability of the protein was unaffected. Furthermore, the reduction in MglB synthesis contrasted with the normal expression of MglA. The high-affinity galactose permease of $E$. coli is encoded by a three-gene operon containing a large intercistronic region with a REP sequence located between the first gene $(m g l B)$ and the two distal genes ( $m g l A$ and $m g l C$ ) (Hogg et al., 1991). Previous studies of the $m g l B A C$ operon have revealed the presence of two mRNA populations (Hogg et al., 1991): one mRNA (mglB mRNA) of approximately 1400 nucleotides corresponds to the $5^{\prime}$ region of the operon extending to the intergenic space between $m g l B$ and $m g l A$, and a larger $m R N A$ (mglBAC mRNA), about 4300 nucleotides long, represents the entire operon and is present at less than $1 / 10$ of the level of the smaller mRNA population. The following results show that the stability of the $\mathrm{mg} / \mathrm{B}$ mRNA is decreased in the dnaK756 mutant. Cells of the dnaK756 mutant and of the parental strain in exponential phase at $30^{\circ} \mathrm{C}$ were treated with rifampicin to inhibit the initiation of RNA synthesis. After appropriate time intervals, samples were taken and the RNA was examined by Northern blotting with a probe complementary to residues 398-419 of $m g / B$ (Fig. 6). In the parental strain, the 1400 nucleotide $m g l B \mathrm{mRNA}$ displayed a half-life of 6 min, similar to that of other mRNAs stabilized by REP sequences such as the malE (Hogg et al., 1991) or the bisP mRNAs (Stern et al., 1988), whereas in the dnaK756 mutant, the half-life of the $m g l B m R N A$ was reduced to less than $1 \mathrm{~min}$. The decrease in stability of the $\mathrm{mg} / B$ $m R N A$ correlated with the decrease in galactose transport activity (Fig. 1a), in the level of $\mathrm{MglB}$ (Fig. 1b) and in MglB synthesis (Fig. 2a) in the dnaK mutant. The normal expression and synthesis of $\mathrm{MglA}$ in the $d n a K$ mutant suggests that transcription rates of the mglB AC operon, stability of the $m g l B A C \mathrm{mRNA}$ and translation of the $m g l A$ gene are not significantly affected in the mutant [the stability of the $m g l B A C \mathrm{mRNA}$ could not be determined due to a low hybridization signal with the probe (not shown)]. The decreased MglB expression (Fig. 1b) resulted from a decreased synthesis of the protein (Fig. 2a) and correlated with a decreased stability of the $m g / B$ mRNA (Fig. 6). The lesser stability of the $m g l B$ mRNA might result from an effect of the $d n a K$ mutation on the stability of the $m g / B \mathrm{mRNA}$, perhaps linked to the presence of the REP sequence at the $3^{\prime}$ extremity of this mRNA, or from an effect of the dnaK mutation on translation rates of the $m g l B m R N A$ with a consequent decrease in its stability (see Discussion).

\section{DISCUSSION}

In the present report, we show that export and expression of the periplasmic galactose receptor $\mathrm{MglB}$ are defective in a dna $K$ mutant. The defect in export is reflected in an accumulation of pre-MglB in the dnaK756 temperaturesensitive mutant at the restrictive temperature and the defect in expression in reduced MglB synthesis in the mutant (even in conditions where export is not significantly affected). The decreased MglB synthesis correlates with a reduced stability of the $m g l B$ mRNA.

Several results suggest that heat shock proteins function as chaperones in protein export: the GroEL/GroES complex appears to be the primary chaperone for the export of $\beta$-lactamase (Kusukawa et al., 1989). DnaK and DnaJ are involved in the export of alkaline phosphatase, a SecB-independent protein (Wild et al, 1992), and the maltose receptor MalF and the maltoporin LamB in a SecB null mutant (Wild et al., 1992). It has not been determined whether DnaK (like SecB which functions both as a chaperone and as a pilot protein) helps to target the precursor protein to the translocase or functions solely to maintain the precursor in an export-competent conformation. The present results suggest that DnaK does not substitute for SecB in $\mathrm{MglB}$ export, and that it does not eliminate the need for the SecA component of the translocase, thus favouring the hypothesis of an early interaction of the DnaK chaperone with nascent pre$\mathrm{MglB}$ and subsequent transfer of the pre-protein to SecB, $\operatorname{Sec} A$ and $\operatorname{Sec} Y / E$.

The synthesis of $\mathrm{MglB}$ is reduced in the dnaK mutant (whereas the synthesis of $\mathrm{MglA}$, which is expressed from the same operon, is not affected) and the lower synthesis of $\mathrm{MglB}$ correlates with a decreased stability of the $\mathrm{mglB}$ $m R N A$. The $m g l B$ mRNA derives from the polycistronic $m g / B A C \mathrm{mRNA}$, and is stabilized against $3^{\prime}-5^{\prime}$ exonucleases by a REP sequence located at its $3^{\prime}$ extremity (Hogg et al., 1991; Newbury et al., 1987a, b; Stern et al., 1988). It has been shown previously for the malEFG 
(maltose transport operon) and bisPJQ (histidine transport operon) transcripts of E. coli, that the $5^{\prime} \mathrm{mRNA}$ segment is stabilized against exonucleases by an intercistronic stem-loop REP sequence located at the $3^{\prime}$ end of malE and bisP (Newbury et al., 1987a, b; Stern et al., 1988). Stabilization of the upstream malE and bis $P$ $m R N A s$ by REP sequences is responsible in part for the high expression of the MalE and HisP proteins, and deletion of these REP sequences destabilizes the upstream $m a l E$ and bisP messages and reduces the expression of MalE and HisP. The decreased stability of the $m g / B$ mRNA in the dnaK mutant might result from a defect in the stabilization of this mRNA by its $3^{\prime}$-located REP sequence. A direct interaction between DnaK and REP sequences seems unlikely, since DnaK does not possess the features of a RNA-binding protein [its AT'Pase activity is not affected by nucleic acids but is stimulated by peptides and unfolded proteins (reviewed in Georgopoulos et al., 1994)]. The chaperone might, however, be implicated in the expression of proteins involved in the stabilization of mRNAs by REP sequences (Causton $e$ tal, 1994), or in the activity of the multiprotein complex involved in mRNA degradation (Causton $e t$ al., 1994; Py et al., 1994; Carpoussis et al., 1994), in the same way that it is implicated in the activity of the multiprotein complex involved in the replication of Lambda phages (Georgopoulos et al., 1994). The implication of DnaK in mRNA stability might be restricted to a select subset of mRNAs, since the heat shock response does not appear to affect the stability of total mRNAs (Henry et al., 1992). The chaperone GroEL has been recently identified as a constituent of an mRNA-protection complex in E. coli (Georgellis tt al., 1995).

Alternatively, the decreased stability of the $m g l B m R N A$ in the $d n a K$ mutant might be due to a decreased translation tate of the $m g / B \mathrm{mRNA}$. It has been frequently observed that translation rates can affect the stability of mRNA molecules (Wagner et al., 1994; Yarchuk et al., 1992; Schneider et al., 1978; reviewed in Petersen, 1993), and that synchronization of transcription and translation is important for the stability of nascent bacterial mRNAs (Wagner et al., 1994; Iost \& Dreyfus, 1995). DnaK is known to interact with nascent proteins (Hendrick $e t$ al., 1993; Gaitanaris et al., 1994), and the chaperone might interact more specifically with exported proteins (particularly with their signal sequence) than with cytoplasmic proteins. Signal sequence mutations can teduce the synthesis of exported proteins (Hall et al., 1983; Puziss et al., 1989, 1992), and in some cases this reduction occurs independently of an export defect (Puziss et al., 1992). There might be some coupling between a DnaK-dependent folding of $\mathrm{MglB}$ and translation rates of the $\mathrm{mg} / \mathrm{B}$ $\mathrm{mRNA}$, leading to a decreased stability of the message in a dnaK mutant. A cooperation between the translation machinery and yeast hsp $70 \mathrm{~s}$ of the Ssb class has been reported (Nelson et al., 1992), and DnaK appears to regulate synthesis of the heat shock Sigma factor $\sigma^{32}$ at the translational level by interacting with a distinct tegion of the nascent protein (Nagai et al., 1994). Several tesults suggest that in E. coli, $4.5 \mathrm{~S}$ RNA regulates translation to allow proteins to fold properly, and that the Ffh $/ 4 \cdot 5 \mathrm{~S}$ RNA complex couples translation of exported proteins to membrane translocation (Luirink \& Dobberstein, 1994; Brown, 1991; Phillips \& Silhavy, 1992). The DnaK/ hsp 70 chaperones might also be involved in such coupling processes associated with protein folding and protein export.

\section{ACKNOWLEDGEMENTS}

We thank Drs J. Beckwith, K. Ito, C. Kumamoto, J. C. Walker and C. Georgopoulos for gifts of bacterial strains, Dr Philippe Régnier, Institut de Biologie Physico-chimique, Paris, for critical reading of the manuscript, and A. Bracone for technical assistance.

\section{REFERENCES}

Bardwell, J. C. \& Craig, E. A. (1984). Major heat shock gene of Drasopbila and Escbericbia coli heat inducible dnaK gene are homologous. Proc Natl Acad Sci 81, 848-852.

Brown, S. (1991). 4.5S RNA: does form predict function? Nen Biol 3, 430-438.

Bukau, B. \& Walker, G. C. (1989). Cellular defects caused by deletion of the Escbericbia coli dnaK gene indicate roles for heat shock protein in normal metabolism. J Bacteriol 171, 2337. 2346.

Bukau, B., Reilly, P., McCarty, J. \& Walker, G. C. (1993). Immunogold localization of the DnaK heat shock protein in Escherichia coli cells. J Gen Microbiol 139, 95-99.

Carpoussis, A. J., Van Houwe, G., Ehretsman, C. \& Krisch, H. M. (1994). Copurification of E. coli RNAase $E$ and PNPase: evidence for a specific association between two enzymes important in RNA processing and degradation. Cell 76, 889-900.

Causton, H., Py, B., McLaren, R. S. \& Higgins, C. F. (1994). mRNA degradation in Escherichia coli: a novel factor which impedes the exoribonucleolytic action of PNPase at stem-loop structures. Mol Microbiol 14, 731-741.

Economou, A. Z. \& Wickner, W. (1994). Sec A promotes preprotein translocation by undergoing ATP-driven cycles of membrane insertion and deinsertion. Cell 78, 835-843.

El Yaagoubi, A., Kohiyama, M. \& Richarme, G. (1994). Localization of DnaK (chaperone 70) from Escherichia coli in an osmotic-shocksensitive compartment of the cytoplasm. J Bacteriol 176, 7074-7078.

Ellis, R. J. \& van der Vies, S.M. (1991). Molecular chaperones. Annu Rev Biocbem 60, 321-347.

Gaitanaris, G. A., Vysokanov, A., Hung, S. C., Gottesman, M. E. \& Gragerov, A. (1994). Successive action of Eschericbia coli chaperones in viwo. Mol Microbial 14, 861-869.

Georgellis, D., Sohlberg, B., Hartl, F. U. \& von Gabain, A. (1995). Identification of GroEL as a constituent of an mRNA-protection complex in Escbericbia coli. Mol Microbiol 16, 1259-1268.

Georgopoulos, C. (1977). A new bacterial gene which affects lambda DNA replication. Mol Gen Genet 151, 35-39.

Georgopoulos, C., Liberek, K., Zylicz, M. \& Ang, D. (1994). Properties of the heat shock proteins of $E$. coli and the autoregulation of the heat shock response. In The Biology of the Heat Sbock Proteins and Molecular Chaperones, Pp. 209-250. Edited by R. I. 
Morimoto, A. Tissières \& C. Georgopoulos. Cold Spring Harbor, NY: Cold Spring Harbor Laboratory Press.

Gross, C. A., Strauss, D. B., Erickson, J. W. \& Yura, T. (1990). The function and regulation of heat shock proteins in Escbericbia coli. In Stress Proteins in Biology and Medicine, pp. 166-190. Edited by R. Morimoto, A. Tissieres \& C. Georgopoulos. Cold Spring Harbor, NY: Cold Spring Harbor Laboratory Press.

Hall, M. N., Gabay, J. \& Schwartz, M. (1983). Evidence for a coupling of synthesis and export of an outer membrane protein in Eschericbia coli. EMBO J 2, 15-19.

Harayama, S., Bollinger, J., Lino, T. \& Hazelbauer, G. (1983). Characterization of the $\mathrm{mgl}$ operon of Escherichia coli by transposon mutagenesis and molecular cloning. J Bacteriol 153, 408-415.

Hendrick, J. P. \& Hartl, F. U. (1993). Molecular chaperone functions of heat shock proteins. Annu Rev Biochem 62, 349-384.

Hendrick, J. P., Langer, T., Davis, Y. A., Hartl, F. U. \& Wiedmann, M. (1993). Control of folding and membrane translocation by binding of the chaperone Dna J to nascent polypeptides. Proc Natl Acad Sci 90, 10216-10220.

Henry, M. D., Yancey, S. D. \& Kushner, S. R. (1992). Role of the heat shock response in stability of $\mathrm{mRN} A$ in Escherichia coli $\mathrm{K}-12$. I Bacteriol 174, 743-748.

Hogg, R. W., Voelker, C. \& von Carlowitz, I. (1991). Nucleotide sequence and analysis of the $\mathrm{mgl}$ operon of Escherichia coli K12. Mol Gen Genet 229, 453-459.

Iost, I. \& Dreyfus, M. (1995). The stability of Escbericbia coli lac Z mRNA depends upon the simultaneity of its synthesis and translation. EMBO J 14, 3252-3261.

Ito, K., Bassford, P. J. \& Beckwith, J. (1981). Protein localization in E. coli: is there a common step in the secretion of petiplasmic and outer-membrane proteins? Cell 24, 707-717.

Ito, K., Wittekind, M., Nomura, M., Shiba, K., Yura, T., Miura, A. \& Nashimoto, H. (1983). A temperature-sensitive mutant of $E$. coli exhibiting slow processing of exported proteins. Cell 32, 789-797.

Kumamoto, C. A. \& Beckwith, J. (1983). Mutations in a new gene $\sec B$ cause defective protein localization in Escbericbia coli. J Bacteriol $154,253-260$.

Kusukawa, N., Yura, T., Ueguchi, C., Akiyama, Y. \& Ito, K. (1989). Effects of mutations in heat shock genes groES and groEL on protein export in Escherichia coli. EMBO J 8, 3517-3521.

Luirink, J. \& Dobberstein, B. (1994). Mammalian and Escherichia coli signal recognition particles. Mol Microbiol 11, $9-13$.

Maniatis, T., Fritsch, E. F. \& Sambrook, J. (1982). Molecular Cloning: a Laboratory Manual. Cold Spring Harbour, NY: Cold Spring Harbour Laboratory.

Manson, M. D., Boos, W., Bassford, P. J. \& Rasmussen, B. A. (1985). Dependence of maltose transport and chemotaxis on the amount of maltose binding protein. J Biol Cbem 260, 9727-9733.

Meury, J. \& Kohiyama, M. (1991). Role of the heat shock protein DnaK in osmotic adaptation of Eschericbia coli. J Bacteriol 173, 4404-4410.

Miller, J. H. (1972). Experiments in Molecular Genetics. Cold Spring Harbor, NY: Cold Spring Harbor Laboratory.

Nagai, H., Yuzawa, H., Kanemori, M. \& Yura, T. (1994). A distinct element of the $\sigma^{32}$ polypeptide is involved in DnaK-mediated negative control of the heat shock response in Escherichia coli. Proc Natl Acad Sci 91, 1028010284.

Nelson, R. J., Ziegelhoffer, T., Nicolet, C., Werner-Washburne, M. \& Craigh, E. A. (1992). The translation machinery and $70 \mathrm{kd}$ heat shock protein cooperate in protein synthesis. Cell 71, 97-105.

Newbury, S., Smith, N. H., Robinson, E. C., Hiles، I. D. \& Higgins,
C. F. (1987a). Stabilization of translationally active $m R N A$ by prokaryotic REP sequences. Cell 48, 297-310.

Newbury, S. F., Smith, N. H. \& Higgins, C. F. (1987b). Differential mRNA stability controls relative gene expression within a polycistronic operon. Cell 51, 11311143.

Nossal, N. G. \& Heppel, L. A. (1966). The release of enzymes by osmotic shock from Escbericbia coli in exponential phase. J Biol Cbem 241, 3055-3062.

Oliver, D. B. \& Beckwith, J. (1981). E. coli mutant pleiotropically defective in the export of secreted proteins. Cell 30, 765--772.

Paek, K. H. \& Walker, G. C. (1987). Eschericbia coli null mutants are inviable at high temperature. J Bacteriol 169, 283-290.

Petersen, C. (1993). Translation and mRNA stability in bacteria: a complex relationship. In Control of Messenger RNA Stability, pp. 117-160. Edited by J. Balasco \& G. Brawerman. San Diego: Academic Press.

Phillips, G. J. \& Silhavy، T. J. (1992). The E. coliffb gene is necessary for viability and efficient protein export. Nature 359, 744-746.

Powers, E. L. \& Randall, L. L. (1995). Export of the galactosebinding protein in Escherichia coli depends on the chaperone SecB. J Bacteriol 177, 19061907.

Puziss, J. W., Fikes, J. D. \& Bassford, P. J. (1989). Analysis of mutational alterations in the hydrophilic segment of the maltose binding protein signal peptide. J Bacteriol 171, 2303-2311.

Puziss, J. W., Harvey, R. J. \& Bassford, P. J. (1992). Alterations in the hydrophilic segment of the maltose binding protein signal peptide that affects either export or translation of MBP. / Batteriol 174, 6488-6497.

Py, B., Cauton, H., Mudd, E. A. \& Higgins, C. F. (1994). A protein complex mediating mRNA degradation in Escherichia coli. Mol Microbiol 14, 717-729.

Richarme, G. (1983). Associative properties of the Escherichia coli galactose binding protein and maltose binding prorein. Biochim Bioplyys Acta 748, 99-108.

Richarme, G., El Yaagoubi, A. \& Kohiyama, M. (1993). The MglA component of the binding protein-dependent galactose transpott system of Salmonella typhimurium is a galactose-stimulated ATPase. J Biol Cbem 32, 24074-24077.

Schneider, E., Blundell, M. \& Kennell, D. (1978). Translation and mRNA decay. Mol Gen Genet 160, 121-129.

Shi, W., Zhou, Y., Wild, J., Adler, J. \& Gross, C. A. (1992). DnaK, Dna J, and GrpE are required for flagellum synthesis in Escbericbia coli. J Bacteriol 174, 6256-6263.

Stern, M. J., Prossnitz, E. \& Ferro-Luzzi Ames, G. (1988). Role of the intercistronic region in post-transcriptional control of gene expression in the histidine transport operon of Salmonela typhimurium: involvement of REP sequences. Mol Microbiol 2 , 141-152.

Towbin, H., Staehelin, T. \& Gordon, J. (1979). Electrophoretic transfer of protein from polyacrylamide gels to nitrocellulose sheets: procedure and some applications. Proc Natl Acad Si 76 , $4350-4354$.

Wagner, L. A., Gesteland, R. F., Dayhuff, T. J. \& Weiss, R. B. (1994). An efficient Shine-Dalgarno sequence but not translation is necessary for lac Z mRNA stability in Escherichia coli. J Bacteriol 176, 1683-1688.

Wild, J., Altman, E., Yura, T. \& Gross, C. A. (1992). DnaK and Dna J heat shock proteins participate in protein export in Escherichia coli. Genes Dev 6, 1165-1172. 
Wu, B., Georgopoulos, C. \& Ang, D. (1992). The essential E. coli $m s g B$ gene, a multicopy suppressor of a temperature-sensitive allele of the heat shock gene grpE, is identical to dapE. J Battariol 174, 5258-5264.

Yarchuk, O., Jacques, N., Guillerez, I. \& Dreyfus, M. (1992).
Interdependence of translation, transcription and mRNA degradation in the lac $Z$ gene. $\int$ Mol Biol 226, 581-596.

Received 23 February 1996; revised 23 May 1996; accepted 29 May 1996. 